\title{
Assessing Roles of English Language Teachers: In the Case of Wollo University
}

\author{
Mekuriaw Genanew Asratie \\ Department of English Language and Literature, College of Social Sciences and Humanities, Injibara University, Injibara, Ethiopia \\ Email address: \\ yohanismekuriaye29@gmail.com

\section{To cite this article:} \\ Mekuriaw Genanew Asratie. Assessing Roles of English Language Teachers: In the Case of Wollo University. International Journal of \\ Elementary Education. Vol. 9, No. 4, 2020, pp. 77-87. doi: 10.11648/j.ijeedu.20200904.11
}

Received: September 23, 2020; Accepted: October 9, 2020; Published: November 23, 2020

\begin{abstract}
Teaching is demanding and complex task. Everything is needed to be molded or activated and changed based up on teachers' role in general. The current study focuses on roles of teachers who are teaching English as foreign or second language at Wollo University particularly. The research was conducted by using descriptive design with incorporating qualitative approach. The total population of the study was 48. The sample of the study was selected through random sampling design in general and availability technique in particular. The data collection instruments were semi-structured interview and classroom observation. The data gathered by using these tools were analyzed qualitatively based on their theme. The research results revealed that English teachers' responsibilities were managing the teaching and learning methods and activities inside classroom, facilitating, advising, assessing, researching, reviewing and planning the lesson. Additionally, some teachers have few difficulties while teaching. Based on the results, the researcher recommended that the fund should be outflowed for educational purposes, teachers should take part in training opportunities, create constant awareness on Pedagogic Graduate Diploma teaching training, teachers should be recruited based on their interest of teaching, and the teachers should review their teaching process.
\end{abstract}

Keywords: Roles, English Language, English Language Teachers

\section{Introduction}

\subsection{Background}

In fact, it is the most important to explain the roles of university English instructors for being a good facilitator in classroom as well as outside. Thus, in this topic, role in university English teacher is two distinct concepts that need elaboration in separation from each other. First, what role means in the aspect of its concept in higher educational institution must be defined clearly. Role, according to the author's view, is different contributions or responsibilities of the worker for their customers and institutions in which they are working. Customers on the other hand, have also such responsibility to perform when they need services from the servants in one institution. Servants can serve those people in terms of social, political, economic, and cultural affairs. Generally, Role is an actor's part, or one's function, what a person is appointed or expected to do. The term Role is sometimes used in the singular teacher role we view it as a multidimensional, dynamic construct. Standard definitions of role emphasize the differentiating "set" of tasks or activities expected of those in social or organizational position. When those activities are work related, they are generally described as tasks. Following and others, we expand the definition English language teachers' qualification, professional training, command on the subject, aptitude and attitude, dedication to the job, sense of responsibility, school of thought etc. It is defined as the part of someone who performs in the organization. [1-3]. These potentially conflicting roles have been described in many ways.

In other words, once institutional employer has to help the people who live around him/herself in physical as well as mental perspectives. Service users have the right to get the admission of what and how to change everything in to valuable credits in their daily lives. To do so, all lecturers at university in Ethiopia are pledged to recognize what they have to bring the services for the people close and behind to them. And then, students on their side, must apply different relevant roles in English classroom. Here, it doesn't mean 
they always do different responsibilities only in English classroom rather than other subjects at university. But this paper focuses on responsibilities in which teachers and students at university can complete in English classroom as well as outside the class in particular. Beside to this, especially, English language teachers are the main target concerned bodies in their special subject area in higher educational institution in Ethiopia. In relation with this, university English teachers perhaps understood as the person who is graduated in English field and licensed in teaching English language in particular to give instruction for those who are following their study in different subject areas. Whereas, those who attend different courses individual department at university, are called learners. Hence, we all English teachers have unlimited roles to complete in such institution. And students on their hand have to complete their roles on the basis of educational curriculum and university legislation rules. Regarding to role, teachers at university can be help students apply concepts, such as math, English, and science through classroom interaction and presentations. Their role is also to prepare lessons, grade papers, manage the classroom, meet with parents, and work closely with school staff [4]. Being a teacher is much more than just executing lesson plans, in today's world a teacher's role is a multifaceted profession; they carry the role of a surrogate parent, class disciplinarian, mentor, book keeper, role model, planner etc. Similarly, learners perhaps, be active to be beneficiaries from various types language programs and from their teacher that they brought teaching materials to them.

Moreover, teachers are responsible for communicating effectively all curricula contents [5]. Organizing English classroom used to keep classes in order to organize teaching procedures, to arouse students' behaviors, to control discipline in classroom and to implement language teaching in the process of English teaching. They also have the role to facilitate the communication process between all participants in the classroom, and between these participants and the various activities and texts. These roles imply a set of secondary roles for the teacher; first as an organizer of resources and as a resource himself/herself, second as a guide within the classroom procedures and activities. A third role for the teacher is that of researcher and learner, with much to contribute in terms of appropriate knowledge and abilities, actual and observed experience of the nature of learning and organizational capacities. Other roles assumed for teacher are needs analyst, counselor and group process manager. Learners should be responsible for their own learning and use opportunities to practice language actively [6].

Due to the changes of university English teaching in terms of curriculum goals, modern technologies and market demands, it is expected that English teachers should transform their roles from being traditional language teachers to being trainers, organizers, promoters, learners and researchers [7]. The roles of university teachers are complicated to define as there are many classifications of a university lecturer's role. Lecturers now recognize the importance of fostering key skills and competencies.
However, supporting and implementing these measures necessitates a shift in the academic and professional role of lecturers. [8]. There are twelve roles of lecturer which are grouped into six categories: the information provider, the role-model, the facilitator, the assessor, the planner and the resource developer. Not all the teachers aware of all these roles as some of the teachers would play all these roles while others played fewer roles [9]. Thus trainings need to be enforced to teachers so they utilize these twelve roles framework. However, students are no less than teachers, have unique knowledge and perspectives that can make reform efforts more successful and improve their implementation, students' views can help mobilize staff and parent opinion in favor of meaningful reform; generally, their involvement is fundamental to all improvement [10].

In connection with teachers' role, seven qualities of successful teachers in which the first three qualities are the skills of successful teachers such in subject competency, creativity, flexibility in using expertise and motivation [11].

While the remaining seven qualities are personality and attitudes of the teachers such as willingness to take risks and make mistakes, respect for learners, caring, warmth, love and sense of humor, pride in the profession and a willingness to go the extra mile. This can show that being effective teacher in all aspects is also the role that they are required by the higher educational institution. Teaching and instructions given in classrooms are influenced by the teachers' knowledge, beliefs and opinions [12].

This is supported by different researchers; individuals' beliefs strongly affect their behavior, actions or roles what they perform in teaching and learning language [13]. Teachers' actions in the classrooms are determined by their beliefs and their beliefs are determined by their actions which influence their roles in the class.

There are three parts of cognitive processes such as teacher planning, thoughts and decisions and theories and beliefs Theories and beliefs of the teachers influence their roles. In order to know the roles language teachers, play in their classrooms, it is imperative to understand about their cognitive processes. In a study analyzing roles of language teachers found two dimensions which form four quadrants associated with the effectiveness of English teachers. English teachers in China distributed roles of current English teachers based on these characteristics of each quadrant. The complicated and conflicting roles of English teachers in China are caused by the demands of schools, the government, the market and the students. They suggest that any qualified college English teachers need to realize the existence of such contradictions so they know how to play their roles accordingly so dialectical way of thinking is imperative $[14,15]$.

\subsection{Statement of the Problem}

Teaching is demanding and complex task. It is like an art. So, teachers are act as an artist in his or her class while teaching. They are highly demanded by the students and other people to change the way that people's social, cultural, political and economic affairs. Teachers are the precious 
servants according to the writer's view. Because everything is needed to be molded or activated and changed based up on teachers' role, they can contribute unlimited efforts for once country development. Especially, English teachers apply in such a way to make the students free from anxiety, suspense to follow what the teacher is talking with them in classroom. Beside to this, teachers' role at university can be the crucial part from other issues that the rule and regulations of university commands to be performed.

In our case, there also several governmental and private universities they are serving the people in different aspects in the real world. In these higher educational institutions, people who are employed to serve the people in way that the people required them to get any helps concerning to teaching as well as other things. Some teachers' roles require more practical expertise and others more educational expertise. Some roles have more direct face-to-face contact with students and others less. The roles are presented in a 'competing values' framework they may convey conflicting messages, for example. Providing information or encouraging independent learning, helping the student or examining their competence. The role model framework is of use in the assessment of the needs for staff to implement a curriculum, in the appointment and promotion of teachers and in the organization of a staff development program. Some teachers will have only one role. Most teachers will have several roles. All roles, however, need to be represented in an institution or teaching organization.

Even though the role of teachers at university is the most and foremost crucial issue, most of the teachers don't involve on whatever they are required to do explicitly. The author himself had seen and heard university teachers' unexpected activities on students. Students themselves were troubled in such a way on their learning process. For example, they were obliged to make withdraw for one and above year. And they were also academically dismissed when they never complete the action that their teacher is interested. The author is interested to write and present on this topic for he has seen those problems and he is the prospect English lecturer for university. So, he assumed that, before engaging in his career, it is too important to realize the activities or roles that he is going to carry out at the university through presenting such papers with his colleagues and instructor. Thus, at least it necessitates minimizing such problems whether by conducting action research or discussing with the concerned bodies before inventing the problem at university. The collector of this seminar explained the issues that the university teachers have the charge to perform in the way that they are giving education is the goal of this paper. This paper mainly is focused English teachers at university in our case based on the already chosen topic "roles of university English teachers". To more ideas and understanding about teachers' role at university, it is vital to write works related with the present title of the seminar paper.

\subsection{Objectives of the Research}

\subsubsection{General Objective}

The main intent of this study was exploring the English language teachers' roles that are performed at university prominently.

\subsubsection{Specific Objectives}

The Specific objectives of the study were to

1. Look for roles of English language teachers at Wollo University.

2. Identify the problems that obstruct English language teachers while they are teaching at university.

\subsection{Research Questions}

To address the solutions for the problems and meet the intended objectives, it is vital to draw the clarified questions.

1. What are English Language teachers' roles at Wollo University?

2. What are the obstacles that hinder English language teachers from applying role at Wollo University?

\subsection{Delimitation of the Study}

The paper was delimited geographically at Wollo University Dessie main campus. The campus itself is located the north west of the main town for South Wollo zonal administration in Amhara region. It is estimated that four $\mathrm{km}$ far from the town. And conceptually, it was about English language teachers roles basically, characteristics of good teachers, students' functions at university with their teachers and classmates at school, problems that hinder from completing the legislations of university that is interested in can be the further issues that are incorporated with the main target of the delimitation of the paper.

\subsection{Significance of the Research}

The result of the current study may be significant for English language teachers, students, educational institutions and researchers.

First, English language teachers in general perhaps are the beneficiaries from this study. New teachers in particular may get the hint about their roles in teaching English language at university.

Students also will be benefitted from the result of this study through reading it from a journal if it will be published online or in print. It helps them by providing the information about what roles their teachers should have and learn accordingly.

Another significance may be for academic institutions. It will help them as an indicator there is the gap in teachers' teaching professions, so they decide to create teachers awareness on teaching role, develop university legislation on the base of teachers' need and roles, and establish continuous professional development.

Finally, the researchers who are interested in related to this issue may use as reference for their study.

\section{Review of Related Literature}

\subsection{Concepts on Teaching and Teachers' Roles}

In this day, and in English teaching, students are the 
implementers, while teachers play different roles during this process. Teachers are conductors, guiding students to start activities. They are directors, designing scenarios for the activities and assigning roles to students. They are also critics, evaluating students' oral expression writing and listing etc. appropriately. The appropriateness of roles that teachers play can change the traditional English teaching which is teachercentered. In this way, teachers can develop students' initiatives to a large extent and improve their abilities of language expression in English. Teachers should bear in mind that the protagonists of classroom teaching are students, and not teachers. Therefore, teachers should avoid too much input during the course of teaching, which will affect students' output. At the same time, teachers should be aware that they are also the organizer and implementer in classroom teaching besides being a participant. They can provide advice to students and teach them knowledge and ways of learning, but they should remember that students are the main subject of study. Students' input and output positively are the reflection of excellent teaching results. The teacher can help, advise and teach, but only the learner can learn.

\subsection{Teachers' Role at University}

\subsubsection{Teacher as Organizer of Resources}

Students' performance in a classroom is greatly dependent on the quality and the medium by which teachers provide the learning content. [16]. The content is also determined by the material that the teachers use for teaching and learning. With problem-based learning and other student- centered approaches, students are dependent on having appropriate resource material available for use either as individuals or in groups. Even in traditional curricula, students spend as much time with their workbooks as with their teachers. As the title indicated teachers in all level of educational practices are the provider for teaching and learning aids or guides. They are called in other word, material developers or study guide producers. Materials like audio tape, video, $\mathrm{CD}$, power point, printed handbooks etc. which are used to facilitate the teaching learning process. The role of the teacher as resource creator offers exciting possibilities.

Beyond this, teachers are organizing and mobilizing communities of people, and constantly building those communities [17]. Indeed, the vision has been painted of the virtual university in which lecturers are replaced by instructional designers. The new technologies have greatly expanded the formats of learning materials to which the student may have access and make it much easier for the student to take more responsibility for their own education. As developers of resource materials, teachers must keep abreast with changes in technology.

\subsubsection{Teachers as Facilitator}

In the learner-centered method, the teacher plays the role of a guide, providing the proper learning environment for his students to learn to use the language for communication. He or she does not "tell" them but only sets them on the path of self-discovering or self-learning. This venture is possible only when the teacher sets a number of learning tasks for the learners instead of simply making them passively listen to whatever he or she says. Teacher offers help if it is needed (when the learners are missing and they wish help). Teacher helps to provide guidance to students on the activities carried out dialogues between two or group discussion, scenario performance or debate, when to carry out the activities, what activities should be carried out, how to carry them out, and so on. In this way, teachers can activate students' initiatives to expand the variety of teaching activities. The ideal teaching effectiveness can be achieved.

The move to a more student-centred view of learning has required a fundamental shift in the role of the teacher. No longer is the teacher seen predominantly as a dispenser of information or walking tape recorder, but rather as a facilitator or manager of the students' learning. The more responsibility and freedom given to the student, the greater the shift required in the teachers' role. Not all teachers adapt to this different role. Sometimes teachers find the task of facilitator difficulties because of development of new technology. Teacher's traditional roles are nowadays facing more and more challenges in facilitating the activities when teaching [18]. Traditionally, we accept teachers' role is simply informing the students about the subject. But it is contrasted today's teacher's role which is to one of coconstructor of knowledge, a facilitator that guides and activates student learning, while fostering the the necessary skills to succeed in a rapidly changing world and uncharted future. $[19,20]$. This changing role of the teacher is also reflected in the constructivist approach to learning, in which knowledge is 'constructed' in the mind of the student and is constantly evolving [21]. It is the role of the teacher to facilitate this process rather than to act simply as an information provider. The characteristics of an effective teacher are develop relationships with their students, patient, caring, knowledge of learener, and dedication to teaching [22]. Therefore, teachers needed the ability to communicate with students in an informal way in the small groups sessions, and to encourage student learning by creating an atmosphere in which open exchange of ideas was facilitated.

The increasing availability and use of learning resource materials also brings with it the need for the teacher as a learning facilitator. No set of course materials, whether in print or electronic format, is perfect for all students. It is the responsibility of the teacher to facilitate the student use of the resources by overcoming any deficiencies in the materials and by integrating them with the curriculum.

Fostering members' understanding and acceptance of one another, as well as successful communication, requires the development of a sense of belonging to the class, making the teacher's role as the creator of the class atmosphere indispensable. The teacher should ensure a safe, trusting and tolerant classroom environment. Cooperation requires good relationships between peers and a degree of familiarity. The teacher is responsible for establishing and encouraging new contacts and must provide pupils with opportunities to get to know one another. Positive experiences gained during class 
make the students more motivated, which is a key factor in accelerating knowledge acquisition.

\subsubsection{Teachers as an Assessor}

The assessment of the student's competence is one of the most important tasks facing the teacher. Assessing data in schools to make decisions on teaching, instruction and students' learning [23].This duty for teacher is directly related with assessing and testing students' performance and competence through ought their learning ages at university.

Hence, there is no learning and teaching without testing in different ways to recognize whether the students understood or not and is the teacher instructed his students well or not. Here, teachers are called in other word "Quality Education Checkers." They can assess what is going on during teaching - learning process and what happened earlier after teaching learning process. Examining does represent a distinct and potentially separate role for the teacher. Thus, teachers use assessment to determine where his/her students are in the learning process and what teaching processes have worked. Teachers need to be assessed by students, faculty, and administration on their ability to engage. Student feedback is important in order for teachers to get a learners perspective. [24]. It is the expected role of them. The assessment of students is an integral part of teaching, and requires the development of rapport and genuine interest in the student [25]. The assessor role of the teacher is often perceived as different from the other roles. While as information provider, role model, facilitator and curriculum planner, the aim of the teacher is to assist the student in a variety of ways to achieve the course goals, as an assessor the teacher has the role of passing judgment on the student. This is particularly true in summative assessment, but is less so with formative assessment where the boundaries between assessment and teaching become increasingly blurred.

From the researcher's experience, the teacher's role as an assessor is an important one. Given the importance of assessment of student performance in university teaching and in students' lives and careers, instructors are responsible for taking adequate steps to ensure that assessment of students is valid, open, fair, and congruent with course objectives [26]. Students can walk away from bad teaching, but they are unable to do so with regard to assessment [27].

Teachers are also the concerned body on curriculum evaluation. Regarding to this, the teacher has a responsibility not only to plan and implement educational programs and to assess the students' learning, but also to assess the course and curriculum delivered. Monitoring and evaluating the effectiveness of the teaching of courses and curricula is now recognized as an integral part of the educational process. The quality of the teaching and learning process needs to be assessed through student feedback, peer evaluation and assessment of the product of the educational program. Curriculum and teacher evaluation is a form of accountability which emphasizes the obligation of those employed in the education system to be answerable to the public, to the profession, to those who fund the education and to the students themselves. In this sense evaluation is an instrument of management and control. Evaluation is thus part of every teacher's responsibilities. Within the context of the curriculum, however, some teachers may be expected to assume greater responsibility for overall assessment of the teaching and some may have this as a major personal responsibility. The assessment of teaching and of the curriculum can be conducted at an institutional level with the teacher one of the stakeholders in the process. Just as important is the self-evaluation by the teacher of his or her teaching with the individual teachers reflecting on and analyzing their own teaching.

\subsubsection{Teachers as Planners}

Any teachers at university have the charge of planning either curriculum or course what they are going to teach. To do so, schools and postgraduate bodies have education committees charged with the responsibility for planning and implementing the curriculum within their institution at university. Teachers employed by the school and members of the postgraduate institution may be expected to make a contribution to curriculum planning. Teachers can undertake few activities; regarding to this, teachers will have greater impact on their students than their active involvement in the design of a curriculum or course they teach. Curriculum planning is an important role for the teacher [28].

In relation with course planning, the best curriculum in the world will be ineffective if the courses which it comprises have little or no relationship to the curriculum that is in place. Once the principles which underpin the curriculum of the institution have been agreed, detailed planning is then required at the level of the individual course or phase of the curriculum. Traditionally much of the planning was discipline or subject-based. More recently there has been a move to inter-disciplinary or integrated teaching [29]. Such approaches need to be reflected in course design. Course planning, like planning the curriculum as a whole, requires dedicated time of individuals. The task is significantly more demanding in integrated program, but it is generally accepted that this is a small price to pay for the advantages of integrated teaching. Participation in course planning gives the teacher an opportunity to exert a significant influence on the educational process and to design courses which will achieve the learning outcomes specified by the institution. Teachers in higher education, retain a very significant advantage over teachers in other branches of education: their control of the curriculum. Much of the creativity and power in teaching lies in the design of the curriculum: the choice of texts and ideas which become the focus of study, the planning of experiences for students and the means by which achievement is assessed [30]. These define the boundaries of the experience for students. Of course the way in which the curriculum is brought to life is equally important, but the power of good teacher-student interactions is multiplied many times by course design.

\subsubsection{Group Process Manager}

All teachers have to find a classroom style that they are 
comfortable with, and experience is the only tried-and-true way to do this. Meanwhile, here are a few practical pointers that may make managing classroom, a little easier. Teachers need to manage the classroom seating, students' eye contact and his/her eye contact, his/her talking with class, and speech and voice. Teachers stared on two considerations; the first is that they want students sitting fairly close to each other when they are engaged in pair or small-group work. Physical proximity tends to make students more willing to talk to each other because it helps create a sense of group affinity and closeness; having students relatively close to each other also has the practical advantage of helping keep the general noise level down. The second main consideration is that they want to be able to get as close as they can to as many groups as possible so that they can see and hear what students are doing and interact with them easily and naturally.

In classes where desks are easily movable and space is ample, achieving the two goals above is not particularly difficult. For pair or small-group activities, students can simply move their seats closer together, and for all-class activities, they can have students move into a row or semicircle arrangement. Many our country's teachers take it virtually for granted that the best seating pattern is a circle and $U$ shape. For example, it allows students to have more eye contact with each other and quite literally moves the focus of the class away from the teacher, at least to some degree. However, in classes with many students, circles often become so large that students are only close to the classmates sitting to their immediate right and left, and the empty space in the middle becomes a forbidding no man's land that tends to reduce the conversational atmosphere. In contrast, traditional row seating arrangements have the advantage of placing more students close to each other.

Good eye contact is one of the main ways to establish and maintain a sense of student involvement in the lesson, especially when speaking to the whole class. Hence, teachers have to manage such kind of classroom management while teaching. One of the most helpful things teachers can do for students and one of the most important ways to maintain a degree of control and order in the classroom is simply to speak loudly and clearly enough for students to hear you easily. Some teachers can effectively use a firm, quiet voice that motivates students to quiet down precisely so that they can hear what the teacher is saying, but this is a dangerous strategy for beginning teachers to adopt because it tends to work only when the teacher has already established a clear sense of presence and control. For most beginning teachers, the wiser strategy is speaking in a clear, reasonably loud voice that students have little trouble hearing.

Generally, teacher's role as a manger is a very significant and imperative role in managing a class [31]. A Teacher has to plan well in advance regarding handling the classes within the stipulated time, covering academics as well as interpersonal skills with various teaching techniques which is obviously a path to practical approach. An experienced teacher can manage the timings according to their own experience. Perfect classroom management by a teacher using the major mechanisms will lead to success of teachinglearning methods.

\subsubsection{Teacher as a Researcher and Learner}

Beyond to the roles at university, teachers might have the duty to conduct a scientific research that perhaps used for educational institutions and further local people who need improvement and change on the aspect of agriculture, economy, history, religion, and social affairs. To concerns the movement in academia represented by the educational literature, which considers research as a fundamental part of teacher education and seeks ways to conduct it in different settings and principles. They are also learners while teaching. Because I'm extremely agreed with the saying of "learning is through doing." Moreover, teacher-researchers were put into prominence as professional, who like artists, seek the best ways to reach students in the teaching and learning process and, by using different materials, look for the solutions most suitable to their creations $[32,33]$.

From different types of researches, teachers are most of the times, concerned with action research. Here, it must be emphasized; however, that action-research was the concept that came to identify a movement, primarily initiated by teachers. When they received contributions negotiated with specialists from higher education, it was considered that this movement had features that could relate it to the existing concept. Especially, university English teachers the eager action researcher because of that English teaching is special case from other fields which are given for learners. And by its nature, daily practice and assessment are the main ways to encourage the practitioners engaging the research on the way that solved immediately and applied soon after investigation.

\subsection{Challenges on Teachers' Role}

It is obvious that nothing is performed without any obstacles. So, teachers especially those who are instructing English at university face problems while working. The problems might have their own factors that they are created. For example, due to being new instructor for teaching at university, do not emphasis on the legislations of university which present about how to perform teachers' responsibility at university, and a teacher has another duty more than teaching (has two or more professions) this might hinder him/her from performing his/her teaching well. Because of that they lose their time giving for teaching according to the program which is laid by department head or committee.

Finally, the misalignment between materials and the classroom in which they are eventually implemented can be the problem while teachers performing their roles. Because it is directly related with curriculum reviewers, and those professionals do not design the relevant materials for the students' needs. In other word, the designers do not realize who wants what to capture before designed the teaching learning aids. In a sense, it is often seen a mismatch between the perceived needs of our students and the course book content. 


\section{Methodology}

\subsection{Methodology}

The design of the paper was descriptive. Qualitative type is practical to complete the paper. Semi- structured interview, observation, and document analysis were carried out to make the paper more qualified. Sample was selected through the available sampling technique. Samples were whoever the students at university attending their education at Wollo University. After presenting the collected data, the investigator analyzed through qualitative technique according to thematic arrangement of the collected data.

\subsection{Design of the Paper}

To reach the objectives of the paper, it is important to design the relevant one like descriptive research design and qualitative type of data gathering and analyzing it through qualitative technique. The reason the writer carried out such research design and type is that existing problems were described through word expression. And also the researcher used qualitative data methods to collect data. Therefore, it was important to use qualitative data analysis technique.

\subsection{Population}

The target population of the paper was English language teachers and English major students at Wollo University. It was because of the title is concerning on such people. The total population was 48 . From these 12 were teachers and the rests were students.

\subsection{Samples and Sampling Techniques}

To achieve the objectives of the research, it is good to select the students who attended English before and attending it for the time being at Wollo University through availability sampling technique. Because there was no enough time to carry out, samples were the available English language teachers and English major students at Wollo University. Hence, the sampling design was random.

\subsection{Data Collection Instruments}

In order to meet the purposes of the study, the researcher used primary data source which includes interview, classroom observation and document analysis.

\subsubsection{Interview}

Many researchers agree with interview is used in qualitative research. Hence, the researcher applied this tool especially, semi- structured interview. It was employed as a major data collection tool. This method helps the qualitative researcher to get open ended data by supplementing followup questions, probes and comments. It used for providing the data about English language teachers' roles inside and outside classroom. The interview has three questions for English major students and English language teachers at Wollo University. The interviewer recorded the questions and answers while interviewing.

\subsubsection{Classroom Observation}

It is also another primary data source. This method used so as to collect the practical data about teachers role in the classroom. The observation was conducted inside classroom on the basis of the checklists. There was another COobserver with PI-observer to avoid the biased data. And the audio-video recorder was used to get the reliable data. The most important thing in using this tool was to collect the data from classroom.

\subsubsection{Document Analysis}

The legislation of Wollo University was used as the document to get the supplementary information related to the roles of English language teachers at Wollo University. Even if the document consists the roles of all teachers at Wollo University in general, the duties are concerning to English language teachers in particular.

\subsection{Data Collection Procedures}

Through ought the parts of the paper, the researcher passes through several processes. First, the developer of this paper, searched for related works with the present problem. Then, the researcher digs out the questions for interview and administered for samples of the study on roles of English Language teachers at Wollo University. To make the data believable, the interview was conducted with researcher's friends and addressed to both teachers and students. The interview was addressed through our official language in order to understanding each other and saving time. However, questions and the data were written in English language version. Next, the researcher with his co-observer conducted the classroom observation inside classroom. Finally, the supplementary qualitative data were collected from document analysis tool. Here, the researcher used the legislation of Wollo University. After doing these, the collected data were analyzed based on their themes qualitatively through narration.

\section{Data Presentation, Analysis, and Interpretation}

Regarding to this, to analyze and interpret the data collected, the researcher used semi- structured interview, observation, and document analysis. And the discussion of the findings was presented and discussed clearly. In connection with the role of English language teachers at Wollo University, the investigator of this paper arranged the data collected from students and teachers of English foreign language at Wollo University.

\subsection{Data Analysis and Interpretation from Students' and Teachers' Interview}

The main intent of the research was assessing the roles of English foreign language teachers at Wollo University. To meet this objective, the researcher used semi-structure interview as major data collection tool. Hence, the analysis of 
data from the students was displayed below.

Question 1: Can you tell me English teachers' role at university?

Interviewee 1: The first interviewee was female from second year English Language and Literature department. She answered this question "teachers at university have unlimited responsibilities. For example, they have such the role of bring solution for the specific problem at university particularly; those problems are created in relation with teaching and learning, and with the administrative affairs as well as the people around the compass."

Interviewee 2: The second respondent of this question was the trainee on Post Graduate Diploma Teacher (PGDT) in English at Wollo University. He replied that (from his experience at Debre Markos university while he was a student), "the first and foremost role for especially English teachers is that facilitator of teaching learning habits in such a way a good manner inside class and outside the regular session. He added that a high qualified instructor has a role beyond teaching; such as they are working as communication director, president of the university, and other social work officers. In this way, there might be happened the weakness of quality of education at university level because those teachers are tied and busy with work. Thus, they might not have enough time to complete their teaching role on time. Furthermore, the respondent explained this question as the teacher sometimes carried out the research in connection with the problems in English language skills class."

Interviewee 3: Third, this question was addressed to another English teacher at Wollo University. The respondent answered that "we are managing, facilitating, developing the teaching learning materials, and when it is necessary, conducting research curriculum reviewing while we are at university."

Therefore, from the respondents' answer, we can infer that university teachers have a great role to do and contribute professional knowledge related with education as well. For example, they can do research, facilitate the classroom situations, reviewing curriculum. This is important in developing once country economic, social, and cultural development since the major activities are under teaching and learning.

Question 2: What are the difficulties that face you in learning and observe when teachers are teaching?

Interviewee 1: this respondent replied that "we face difficulties while we are learning English as a foreign language. For example, English language teachers sometimes do not facilitate us as expected. They come into class with only handout and give us group discussion and they do not follow what is going on group discussion. Here, the researcher had added another question that was "are all teachers doing this?" his response was that 'no'. In contrast to this some teachers are performing their roles in a successful way.

Interviewee 2: For the second question, another interviewee answered that there is a problem of teachers on their teaching. With different reasons some teachers absent from regular session. Hence, we students do not gate the expected knowledge on the course because time waste and some teachers are not interested in covering the missed class. They rush to finish the course by themselves with in short time.

Interviewee 3: Finally, this interview question was reacted by the teacher who teaches English language at Wollo University. As the teacher replied that "students do not show their enthusiastic for facilitation of teaching learning process. They are not happy for group working, homework, they do not bring textbooks (hand out) into class, they are also disturbing the class by talking side to side while we are teaching instead of giving attention to subject, and sometimes students measure the course through teachers' humanity and strength on the course. The students decide this course is worried even it is more marketable and easy to apply.

Generally, we can understand the respondents' answer from both teachers and students there are the problems that hinder them to perform their duties. Here, it is clear that both teachers and students have to have a role whenever in teaching and learning respectively. Additionally, the analysis shows that there are difficulties in both sides. For instance, in students' side, there is lack of concentration for activities whether inside or outside classroom this is may be because of lack of awareness about the importance of learning English as a foreign language; moreover, it is perhaps some teachers are also interested in teaching. Some teachers are not employed on their interest base.

Question 3: Do you try to evaluate your teaching process? If yes, how? and if no, why?

Interviewee 1: This interview was intended to ask only the English language teachers. The teacher answered "yes", and further, he stated that "I try to evaluate my teaching process on the way that when the students' result is good, teaching process is going on a valuable way. Otherwise, they are failed; the teaching process is not well. So, according to my evaluation result, I conduct classroom research. Based on my research findings, I try to teach my students".

Interviewee 2: Next, the teacher replied that "no". His justification was he believed that the responsibility is teaching and assessing students. He does not give attention for the process of teaching and learning. This is the reason that the teacher confident on the quality of teaching and assessing methods.

Hence, some teachers try to evaluate teaching process. However some does not use different aspects of measurements to evaluate learning and teaching process. Accordingly, quality of education especially English language teaching and learning can be increased when the teachers review their activities and take actions in teaching process. So, evaluating every process is essential for quality work. However, some teachers do not know their roles or responsibilities accordingly. This affects negatively the teaching learning process.

\subsection{Data Analysis of Classroom Observation}

The observation was conducted in the classroom while the 
teacher was teaching "Reading Skills" course block 329 in class at 2:00 AM. First the researcher asked the teacher for permission to be observed. The teacher allowed us to observe any things what is going on in relation with roles of the teacher. Then, both co-and main-observers entered into classroom. The observation was conducted for an hour with the same teacher. After an hour, Basic "Writing Skills" course teacher came into the class when we were inside classroom. The analysis is displayed bellow based up on the checklists of classroom observation.

According to our observation in the first class, the English language teacher was teaching Reading Skills. The teacher was male. He was using slide power point, and was explain ing the ideas and concepts for his students. From his practice in the classroom, the teacher applied different roles in the classroom: facilitating group discussions, giving feedbacks for students, teaching, giving assignments and classwork related with his course Reading Skills. On students' side, some were active participants, but others were not. It is possible consider the teacher as the developer of teaching and learning materials since the observers observed the Reading Skills teacher provided the reading passage material and gave it for students.

The second classroom observation was held in the same class and building on Basic Writing Skills. The teacher was male. At the very beginning, we observed that as soon as the teacher entered into the class, he greeted his students. After this, he identified us and asked who you are. We replied that excuse me, we are MA English students in this Wollo University and conducting a research by ourselves and observing the situations about teachers' roles that is why we are here. The teacher nodded his neck and accepted us to stay till class end. From this it is possible to understand the teacher has the role of identifying and knowing his/her students well. Next, the teacher started his teaching from revision of what he taught previously through questioning the students. Proceeding to his main teaching process, he was teaching about the types of paragraphs. He showed examples for each type, and gave the turn to the students to practice in writing different types of paragraphs according to the ideas given. He observed and helped the students to focus on coherence, unity and cohesion in their writing. The task was given for ten minutes. However, few students were not applying the given task. After the given time completed, the teacher gave comments to some students. And the teacher ordered the students to change their writing with their friend to give and take the comments outside the class. At the end, the teacher summarized the topic. And advised the students regarding with their way of studying and tolerating the violence everywhere they may face. Finally, he showed students' result on mid exam. By the time students who had got lower point, disturb the teacher by chopping off the result paper. However, the teacher had taken advising them in a good manner. Therefore, one can interpret it the teachers' role is not limited in teaching and learning issues rather model in their behavior and show the culture outside and inside the classroom. They have also the role to advise their students, and manage the group and pair works.

\subsection{Data Analysis from Document}

From the document, there are many duties that the teachers must do while in the university. First, the primary duty is that they are required to be a scholar with full devotion to the advancement of the frontiers of knowledge in accordance with the best traditions developed by scholarly circles throughout the world. The teachers should design, develop and implement courses in an area. This is also similar with the data from semi-structure interview and observation.

The best one from the document is that the teachers should contribute to the best of one's ability and as a member of the institution's community to prevalence of orderly conduct and peaceable operations of the institution and to peaceful resolutions of intra-institutional conflicts. From this data, it is possible to understand the teachers' role is not limited only in educational activities the university. Moreover, the teachers consult and advice students and they must submit grade report and exams for the academic unit. The document shows that they perform the extra teaching assignments when compelling circumstances arise in any Academic Unit of the University. Finally, they are expected to engage in research activities.

\subsection{Findings and Discussions}

\subsubsection{Findings}

The main purpose of this paper was to identify the teachers' role at university. It is mainly focused on English teachers at Wollo University for the investigator is the responsible body in this case. So, regarding to teachers' role, there were data collected through semi- structured interview questions from teacher and students. The result showed us there are several roles implemented by teachers. For example, the data from teacher and students revealed that facilitation, classroom management, developing teaching and learning materials, researching and learning, assessing, curriculum reviewing are the core roles of teachers at university. While teachers are teaching and students are learning, they face challenges that hinder them from applying their roles and responsibilities as well. And finally, some teachers can attempt to evaluate their teaching process whether it is well or not without any frameworks to guide them on their evaluation, but some cannot.

\subsubsection{Discussions}

Teachers' role is the most indispensable for the development on different aspects for once higher as well as lower educational institutions. Especially, English teachers have the great responsibilities while they are at university, because as we see the posted proverb on different notice board "English is the gateway in the world", they must accomplish their role to reach the mission of the university. To further this, now a day, English language is becoming the medium of instruction in our country; hence, to very competent professionals, teachers have to act the crucial concerns at university. In relation with this, the findings of this paper revealed that teachers are the prominent and for concerned bodies in educational institutions 
on several issues. For example, according to the responses, teachers have the roles like facilitating classroom, managing, researching (more of the time action or classroom research), assessing, designing curriculum, learning, and etc. However, teachers have the problem with to identify their roles to do so. Even though some teachers have enough capacity to perform their duty, they do not realize their core and crucial responsibility. Sometimes they perform the overlap roles in a once condition for example, while they are teaching in classroom, they are planning the lesson instead of facilitating the classwork activities. In addition, as the classroom observation showed that teachers sometimes do not take care for different sensitive issues such as politics, economic, culture and religion. These all aforementioned issues are the problems with teachers at university.

Regarding to teachers' role, [34] teachers are responsible for the overall direction, education and management of programming, evaluating, reporting, and designing interventions for all students within the classroom.

\section{Conclusions and Recommendations}

In this part, the investigator has drawn the conclusions and recommendations what will be done in the future based on the findings of the research.

\subsection{Conclusions}

According to the results of the study, the conclusion has been drawn bellow.

There are many factors that influence how teachers approach their work and which particular strategies they employ to achieve their goals [35]. The contexts in which teachers work have an important influence on teaching, since different teaching settings involve teachers in different kinds of roles. For example, in some institutions teachers are fairly autonomous and are free to make decisions concerning course goals, materials, teaching methods, and assessment procedures. In other settings these kinds of decisions are made by a supervisor or program director, and the teacher is seen primarily as someone who carries out decisions that have been made by others. Even in situations where teachers have primary responsibility for how they teach, they may assume very different roles within their own classrooms. Some teachers see their role primarily in managerial and organizational terms. They spend a considerable amount of time planning their lessons, monitoring their teaching, and managing student learning and behavior to make sure that their goals are accomplished. Others see their role more as a facilitator, and believe that the best kind of lesson is one that arises out of the dynamics of the teaching-learning situation. In contrast to this, some of teachers do not complete their roles for knowingly or unknowingly. Especially, for new teachers, it is not clear what they can do at university.

\subsection{Recommendations}

Based on the finding, the investigator of this paper would like to suggest and recommend that from ministry of education to students.

First, the suggestion goes through Ethiopian ministry of education; it should launch the tangible and visible teachers' educational, economic, cultural, and social affairs institutions. In a sense, ministry of education should contribute its unlimited roles as minister so as to overcome the problems which come to teachers' role that hinder them from being effective professionals on their specialization. Moreover, it should outflow sufficient fund for teachers training facilities, and teachers must be recruited based on their interest of teaching.

Second, each higher educational institutions should create constant awareness on Pedagogic Graduate Diploma teaching training (how to teach students and how to solve the problems) when different challenges towards to students and teachers.

Teachers should take part in the created chance attentively whenever it is given can be the better way that the can understand and realize their roles at working place. In addition, they should give the opportunity for the students whenever they want to tell teachers' problems and accept what the students already recommended. Generally, teachers should review their teaching process with the paradigm of evaluation.

Students on their hand also should active participants and accept teachers' advice whether inside or outside classroom when their teachers provide activities.

\section{Acknowledgements}

First and foremost, I would like to thanks my almighty God who made everything possible and always help me in all aspects. Second, I would like to thank my classmates for observing with me and encouraged me to conduct such research. English language teachers were also acknowledged from bottom of my heart. I do not forget my families for their unlimited contributions for the accomplishment of my paper, so I must thank them.

\section{References}

[1] Yasmin, F, \& Islam, M. (2018). Academic Roles of English Language Teachers: A Study of the Perceptions of Pakistani Teachers and Students. Journal of Foreign Languages, Cultures and Civilizations. Vol. 6, No. 1. DOI: 10.15640/jflcc.v6n1a.

[2] Oxford Dictionary on Lexicon. (2020). Meaning of role in English. Albany: State university of New York Press.

[3] Turner, R. (2001). Role theory. In J. Turner (Ed.). Handbook of sociological theory. New York: Kluwer academic

[4] Cox. J. (2017). The role of a teacher is multifaceted. The role of a teacher is multifaceted.

[6] Hu. Y. (2009). The Role of Autonomy for Learning English Out-of-class in Chinese Universities. University of Victoria. 
[7] Shafie, L, A. (2010). The Roles of University English Teachers in Malaysia. Journal of Language Teaching and Research, Vol, 1 N0.30. finland.

[8] Boylan, F. O'Keeffe, M. \& O'Rawe, M. (2011). Considering the Shift in Lecturer Roles as Key Skills and Competencies are Fostered in Higher Education Students Today. SRHE Annual Research Conference, Newport, Wales.

[9] Harden. R. M. (2000). The integration ladder: a tool for curriculum planning and evaluation.

[10] Levin. B. (2000). Putting students at the center in education reform. Journal of Educational change.

[11] Tamblyn, P. (2000). Qualities of success: lessons from a teacher career. Education Canada.

[12] Borg, S. (2003). Review article -Teacher cognition in language teaching: A review of research on What Language Teachers Think, Know, Believe, and Do. Language teaching.

[13] Saad, S, M. (2011). The role of teachers' beliefs in ELT curricula innovations. University of Garyounis.

[14] Clark, C. M, \& Peterson, P. L. (1986). Teachers' thought processes. In M. C. Wittrock (Ed.). Handbook of Research on Teaching. New York:

[15] Malcolm J. Benson and Dong. M. (2007). Analysis of the Role of Chinese English Teachers in Higher education institution.

[16] Viswanathan, R. (2013). Esigning Learning Materials For Students. A Gateway To Teacher Development. Journal of Technology for ELT.

[17] Fleischer, C. \& Buchsbaum., A. (2006). When Talking Makes a Difference: Teachers as Organizer. Language Arts Journal of Michigan.

[18] Gu, M.(2018). Challenges and Solutions Faced by China's Teachedrs in the Era of Globalization.

[19] Enero (2018). The teacher as a facilitator: Redefining our role in the classroom.

[20] Davis. M. H, \& Harden. R. M (1999). AMEE Medical Education Guide 15: Problem-based Learning: a practice guide: Medical Teacher.

[21] Brooks. J. G, \& Brooks. M. G. (1993). In search of understanding: The case for constructivist Classrooms. Alexandra VA, Association for Supervision and Curriculum Development.
[22] Peterson-DeLuca, A. (2016). Top Five Qualities of Teachers: According to Students.

[23] N. Hopfenbeck, T. (2018). Assessors for learning': understanding teachers in contexts, Assessment in Education: Principles, Policy \& Practice, 25:5, 439-441, DOI: 10.1080/0969594X.2018.1528684

[24] Downing, A. (2016). Assessing the Assessors. re niversity of Wisconsin-River Falls

[25] Whitman. N. A, \&. Schwenk. T. L. (1984). Preceptors as teachers: A guide to clinical teaching. Of Salt Lake city, university of Utah.

[26] Murray H, Gillese E, Lennon M, Mercer P and Robinson. M. (1996). Ethical principles in for University teaching. Ontario, Society for Teaching for Teaching and learning in higher Education.

[27] Boud. D. (1990). Assessment and the Promotion of Academic Values. Studies in Higher Education

[28] Nisbet. J. (1990). Rapporteur's Report on the evaluation of education programmes: methods, uses and benefits. Scottish Council for Research in Educationa(EDS).

[29] Diamond. R. M. (1998). Designing and Assessing Courses and Curricula: a practical guide. San Francisco.

[30] Harden, R. M, \& Crosby, J. R. (2000). The good teacher is more than a lecturer - the twelve roles Of the teacher. AMEEMediation Educational Guide No 20. University of Dundee.

[31] Toohey. S. (1999). Designing courses for higher education. The Society for Research into Higher Education and open university press.

[32] Archana. S, \& Rani. K. U. (2017). Role of a teacher in English Language Teaching (ELT). International Journal of Educational Science Research. Vol.7.

[33] André, M. E. (2005). Pesquisa, formação e prática docente. In (Org.). O papel da pesquisa na Formaco na paratica dos Prfessores, Sao Paulo: papiru.

[34] Stenhouse, L. (1975). An introduction to curriculum research and development. Londres: Heinemann.

[35] Hubbard. E. (2005). Teachers and Support Staff Working Together. Standards and Guidelines. 